\title{
Kolaž slojevitih tekstova
}

\section{Diana Zalar. 2014. Potjehovi hologrami: studije, eseji i kritike iz književnosti za djecu i mladež. Zagreb: Alfa d. d. 654 str. ISBN 978-953-297-469-0}

DOI: 10.21066/carcl.libri.2016-05(02).0018

Potjehovi hologrami, knjiga intrigantna naziva, svojevrsni je dijakronijski kolaž važnih tekstova autorice Diane Zalar, književne teoretičarke i kritičarke, nastalih od kraja osamdesetih godina do današnjih dana. Tekstovi sabrani u zbirci obuhvaćaju raznolike studije, eseje, kritike, govore na promocijama, prikaze i recenzije knjiga, a donose pregršt razmišljanja i domišljanja o hrvatskim i inozemnim autorima te knjigama za djecu i mlade. S obzirom na vremenski odmak, tematsku raznolikost te činjenicu da su nastajali za potrebe raznolikih prigoda, među sabranim tekstovima ponegdje se može uočiti stilska različitost, no zbirku u cjelini odlikuje jedna važna karakteristika. Naime, rijetko kada nam u ruke može doći knjiga o književnosti koja je pisana gotovo jednako pitko, prožeta zgusnutim konceptima i interpretacijama kao i samo književno djelo. Ta stilska odlika autoričina rukopisa čini ovu zbirku ujednačenom i izuzetno pitkom za čitatelje različitih polazišta, od akademskih istraživača do studenata i laičkih ljubitelja knjige.

Knjiga je podijeljena na deset poglavlja s više potpoglavlja u kojima se sustavno izlažu tekstovi o pojedinim autorima, naslovima ili temama. Tako strukturirano djelo olakšava čitatelju kretanje odabranim temama u pozamašnoj knjizi od šestotinjak stranica. Ipak, ovaj kolaž odabranih tekstova mogli bismo promatrati kroz pet temeljnih tematskih jedinica: studije o prozi (uključujući komparativne analize hrvatskih i inozemnih pisaca), poeziji, slikovnici, drami i kazalištu (recenzije dramskih tekstova i osvrti na kazališne izvedbe) i metodičkim ogledima. Uz ovih pet temeljnih tematskih jedinica, posebno bismo istaknuli još dvije koje zapravo prožimaju zbirku, ali su od posebne važnosti. Jedna su od njih prijevodi poezije i proze s engleskoga i slovenskoga jezika, a drugi anegdotalne bilješke.

Naime, prijevodi proznih i poetskih djela u knjizi su razvrstani nakon odgovarajućih poglavlja (nakon poglavlja o prozi ili poeziji), no zapravo je riječ o autorskim radovima umjetničke vrijednosti koji zaslužuju poseban osvrt. Anegdote iz privatnoga života, i s druženja s piscima, profesorima i studentima utkane su u samo tkivo knjige te često služe kao ilustracija i odmor od zahtjevnijih dijelova štiva. Ove su anegdote vrijedna zapažanja koja oslikavaju autohtona stanja i zbivanja perioda u kojima su tekstovi nastajali, ilustriraju autore s kojima su povezane i duh vremena u kojemu su nastale.

U prvome poglavlju naziva „O romanima i pričama“ nalaze se tekstovi koji su pratili svojedobno nove prozne naslove ili koji osvjetljavaju neke klasike dječje književnosti. Tako je početni tekst poglavlja usmjeren na stvaralaštvo jedne od najvećih hrvatskih spisateljica, Ivane Brlić-Mažuranić. Kao u hologramskim prikazima najavljenima u naslovu knjige, autorica u početnim tekstovima projicira mitološka bića kroz raznolike prizme, od usmene književnosti, zatim originalnih Priča iz davnine i njihova transponiranja u djelu Snježane Grković-Janović, sve do digitalnih adaptacija Priča koje je izdala Bulaja naklada. Komparativni postupci nastavljaju se i u tekstu u kojemu se autorica bavi usporedbom lingvističko-stilskih postupaka u priči Trude Stamać s postupcima stvaranja lika djedice Neumijke u originalnoj priči.

Tekstovi koji slijede nastavljaju se baviti pojedinim autorom i njegovim proznim stvaralaštvom. Prije svega, to su detaljne studije stvaralaštva autora Đure Sudete, Ivana 
Kušana, Paje Kanižaja, Anđelke Martić, Sunčane Škrinjarić te suvremenijih autora kao što su Snježana Grković-Janović, Hrvoje Kovačević, Nada Mihoković-Kumrić i Maja BrajkoLivaković. U takvim se tekstovima redovito javljaju i različite perspektive; u interpretaciji pojedinoga djela autorica iščitava druge publikacije, u obzir uzima i biografske činjenice, autorove bilješke i intimne razgovore s piscem, što u konačnici pridonosi sveobuhvatnijemu uvidu u stvaralaštvo pojedinoga autora.

Uz opsežnije studije, u poglavlju se nalaze i pojedinačni eseji ili kritike nešto starijih djela ili posve suvremenih naslova autora poput Ivone Šajatović, Blanke Pašagić, Sanje Lovrenčić, Melite Rundek, Mladena Kopjara i dr.

Drugo je poglavlje posvećeno komparativnim studijama u kojima autorica usporedno proučava stvaralaštvo starijih i suvremenijih hrvatskih pisaca (Jože Horvata, Nade Iveljić, Vladimira Nazora, Stanislava Marjanovića, Ane Đokić i brojnih drugih) ili inozemnih velikana poput Hansa Christiana Andersena, Charlesa Perraulta, Philipa Pullmana i dr. Ovdje se ističe tekst o prijevodima suvremene hrvatske dječje književnosti u kojemu autorica sumira brojne doprinose i dosege koje je hrvatska knjiga postigla izvan granica Hrvatske. Komparativne studije tematski su vrlo raznovrsne, ali se najveći broj tema ipak može uključiti u područje u kojemu je autorica vrsna, a to su mitologija i fantastična priča. Ta se sklonost fantastici očituje i u sljedećemu poglavlju, u odabranim autoričinim prijevodima proznih djela, koji, kako je navedeno ranije, doista zaslužuju posebnu pažnju.

Poglavlje posvećeno poeziji donosi tekstove u kojima autorica analizira i interpretira autorske opuse Vesne Parun, Zvonimira Baloga, Ratka Zvrka, Paje Kanižaja, Gustava Krkleca i dr. i pojedine zbirke Luke Paljetka, Rade Brajnovića, Maria Raguža i dr. Prijevodi poezije također su od posebnoga značenja jer se radi o autoričinim prijevodima velikana svjetske dječje poezije, koji nam u suprotnome ne bi bili dostupni: poeziji Shela Silversteina i Roalda Dahla te rimovanome tekstu slikovnice Helen Cooper. Uz prijevode s engleskoga jezika, u zbirci se nalaze i prijevodi sa slovenskoga: pjesme suvremenih slovenskih autora, Andreja Rozmana i Barbare Gregorič.

Poglavlje „O slikovnici“ započinje preglednim tekstom koji se teorijski i povijesno bavi ovom autohtonom vrstom dječje književnosti. Nakon izlaganja o razvoju slikovnice u Hrvatskoj, autorica donosi zaključke o trenutačnim pojavama i suvremenome položaju slikovnice. Tekstovi u nastavku posvećeni su pojedinačnim naslovima stranoga autora, Dicka Brune, i nekolicine hrvatskih autora.

Sljedeća su dva poglavlja posvećena dramskim tekstovima, zbornicima drama i predložaka za igre ili radiodrame te odgledanim kazališnim izvedbama. Spomenuta dva poglavlja veliko su osvježenje jer se bave pomalo zanemarenim žanrovima dječje književnosti i književnosti za mladež. Pritom, osvrti na kazališne predstave artikuliraju doživljaje živoga ostvarenja igrokaza i drama na kazališnim daskama. Na kraju poglavlja nalazi se i jedan osvrt na animirani film iz Disneyjeva studija, Pocahontas, s posebnim osvrtom na izgradnju karaktera u filmu. Šteta je da se u zbirci nalazi samo jedan osvrt ovoga tipa jer ponuđeni tekst daje naslutiti drugačije i originalno čitanje starijih priča u novijemu mediju.

Posljednje poglavlje knjige naziva „Metodičke studije i ogledi“ zaokružuje, ali i nadopunjuje studije iz prethodnih poglavlja jer ukazuje na raznolike mogućnosti interpretacije i drugačija iščitavanja proznih i poetskih djela. Također, u nekoliko priloženih 
tekstova, autorica se bavi općenitijim temama poput čitanja, odnosa mladih prema knjigama te metodama za razvijanje ljubavi prema knjizi i čitanju. Završno poglavlje, a posebice posljednji tekst u knjizi, ujedno je i trenutak otvaranja, svojevrsno vraćanje na početak jer živopisno govori o mladim čitateljima, onima kojima je književnost i namijenjena.

Potjehovi hologrami iscrpna je zbirka studija, eseja, prikaza i ogleda o velikome broju autora i njihovih djela, knjiga koja će zasigurno biti polazište i referencija brojnih novih radova, promišljanja o dječjoj književnosti i književnosti za mladež. Spomenuta raznolikost i raznovrsnost zbirke zasigurno ne dopušta čitanje u jednome dahu, ali poziva čitatelje da joj se iznova vraćaju.

Slojevitost tekstova postignuta je minucioznim i često komparativnim pristupom $\mathrm{u}$ kojemu se autorica oslanja na bogato profesionalno iskustvo, kao i na poznavanje izvanknjiževne zbilje. U posljednjemu tekstu autorica se humoristično ispričava čitatelju na manjku ilustracija u svojoj pozamašnoj knjizi, no istina je da knjiga obiluje ilustracijama. Riječ je o brojnim oživotvorenim slikama poteklima iz opažanja zbilje, druženja s autorima i čitateljima, ponekad utkanima u samo štivo, a ponekad jasno naznačenima u anegdotalnim bilješkama.

To nas zapažanje ponovno vodi na početak - naslov knjige. Hologrami, slike satkane od svjetla, svojega označenika prenose do vremenski i prostorno udaljenoga sugovornika. Odnos književnoga kritičara i knjige u tome je smislu hologramski. Objekt promatranja mijenja se kao i vrijeme i prostor koji ih dijeli, a stoga i značenje koje iz toga odnosa proizlazi. Poput Potjeha, kritičar će se iznova domišljati istini koja je posve hologramska, neuhvatljiva i uvijek fluidna, ali stoga - kao i tekstovi ove zbirke - na materiji ostavlja tragove svjetla koje valja slijediti.

Marina Gabelica

\section{Naratološka početnica}

Maša Grdešić. 2015. Uvod u naratologiju. Zagreb: Leykam international. 228 str. ISBN 978-953-340-027-3

DOI: 10.21066/carcl.libri.2016-05(02).0019

Biblioteka Uvodi koju je pokrenuo zagrebački nakladnik Leykam international posvećena je ključnim temama brojnih društvenih i humanističkih znanosti. Leykamovu propedeutičkomu nakladničkomu nizu 2015. godine pridružilo se šest naslova, a među njima se našla i naratološka početnica. Autorica Maša Grdešić, docentica na Odsjeku za komparativnu književnost zagrebačkoga Filozofskoga fakulteta, oblikovala ju je oslanjajući se na desetogodišnje iskustvo razmatranja i primjene teorije pripovijedi stečeno u nastavnome radu na visokoškolskoj razini. Uvod u naratologiju, svoju drugu autorsku knjigu, autorica je pobliže odredila kao (sustavni) priručnik iz klasične naratologije teksta (8).

U skladu sa zahtjevom biblioteke i svrhom sveučilišnoga udžbenika sadržaj je ograničen na pojmove klasične naratologije. Iscrpnije revizije brojnih pravaca poslijeklasične naratologije opravdano su izostavljene jer premašuju zahtjeve koji se postavljaju pred namjeravane čitatelje - studente koji se upoznaju s određenom disciplinom. Uže područje interesa $u$ ovome uvodu predstavljaju pojmovi povezani s formom teksta, iz čega je 